\title{
Quality Characterisation of Vermicompost Produced from Crop Residue and Cow Dung
}

\author{
Varsha Kumari, Sankar Ch. Paul*, Mahendra Singh, \\ Ajeet Kumar and Amit Kumar Pradhan
}

Bihar Agricultural University, Sabour, Bhagalpur, Bihar-813210, India

*Corresponding author

\begin{abstract}
A B S T R A C T
\section{Keywords}

Vermicompost, Crop residue, Cow dung, Integrated nutrient management

Article Info

Accepted:

07 September 2020

Available Online:

10 October 2020

Properties of fresh vermicompost vary with variation in raw material, composting techniques, species of earthworm used and time of harvest. Feedstock comprises of organic biodegradable waste products like plant biomass and cattle-poultry manure. Therefore, the study was undertaken to characterize the fresh vermicompost generated from three different vermicompost production units (VCPUs) with crop residue biomass and raw cow dung as feeding materials. The bulk density of vermicompost from the different VCPUs ranged between 0.45 to $0.53 \mathrm{~g} \mathrm{~cm}^{-3}$ whereas the particle density varied from 1.04 to $1.06 \mathrm{~g} \mathrm{~cm}^{-3}$ and was a porous organic product. The Moisture content of vermicompost samples were estimated between 37.3 and $40.2 \%$. The maximum water holding capacity had an average value of $387.24 \%$. The $\mathrm{pH}$ and $\mathrm{EC}$ had mean values of 6.88 and $1.81 \mathrm{dSm}^{-1}$ respectively. The average total $\mathrm{N}, \mathrm{P}, \mathrm{K}$ and $\mathrm{S}$ content of the vermicompost samples were found to be $1.41 \%, 0.42 \%, 1.02 \%$ and $0.61 \%$ respectively. The vermicompost samples contain higher numbers of beneficial microorganisms including bacteria, actinomycetes, fungi, rhizobium, PSB, azotobacter etc. along with important enzymes. Microbial biomass carbon content was in the range of 479.76 and $512.84 \mathrm{mg} \mathrm{kg}^{-1}$. Considering all the physico-chemical, biological and biochemical properties the vermicomposts prepared may thus be considered as natural biofertilizers which can be effectively included in integrated nutrient management practices.
\end{abstract}

\section{Introduction}

Agricultural industry plays the major role in the overall economic growth of the world. The increase in demand for food in developing countries has led to tremendous growth in food production around the world. India, with its year-round crop cultivation, generates a large amount of agricultural waste, majorly crop residues. With the increasing multilevel agricultural activities for increasing amount of agricultural products, increases environmental pollution as well as generation of wastes (Bhuvaneshwari, 2019). As per the Glossary of Environment Statistics, United Nations, 1997, agricultural waste includes manure and other wastes from farms, poultry houses and slaughterhouses; harvest waste; fertilizer run-off from fields; pesticides that enter water, air or soils; salt and silt 
drained from fields. According to the Indian Ministry of New and Renewable Energy (MNRE), on an average India generates 500 Million tons (Mt) of crop residue per year (NPMCR, 2014). This report also shows that a majority of this crop residue is in fact used as fodder, fuel for other domestic and industrial purposes. However, there is still a surplus of $140 \mathrm{Mt}$ out of which $92 \mathrm{Mt}$ is burned each year (NPMCR, 2014) in the absence of adequate sustainable management practices causing excessive particulate matter emissions and air pollution. Composting, vermicomposting, farm yard manure and biogas production are a few effective sustainable techniques that can help to curtail the issue while retaining the nutrients present in the crop residue in the soil. Animal wastes also require a route for recycling into valuable end products (Kumar et al., 2018). Composting using earthworm offers the rapid recovery of valuable resources from biodegradable plant and animal wastes to humus-like vermicompost in shorter time duration (Pramanik et al., 2007) Biologically based soil amendments enhances both food safety and environmental well being, which is invaluable to sustainable organic farming systems. Use of vermicompost is an effective way to add organic material in farming and change the soil properties in a positive way by increasing the soil nutrient availability and soil microbial activity (Abbey et al., 2013). Vermicomposting is a bio-oxidative process in which earthworms interact intensively with microorganisms thereby, accelerating the stabilization of organic matter and eventually modifying its physical and biochemical properties (Dominguez, 2004). Thus, vermicompost is the product of composting of biodegradable organic waste carried out by earthworms. Vermicompost comprises of vermicasts and decomposed organic matter. Vermicasts are fine textured and are pure excreta eliminated from the digestive systems of worms (Abbey et al., 2013). Application of vermicompost improves the soil structure by increasing porosity and reducing the bulk density. It improves soil aeration, waterholding capacity, buffer capacity, and cation exchange capacity of soil (Nada et al., 2011). Vermicompost supply sufficient amounts of macro and micronutrients required to promote plant growth and development (Pattnaik and Reddy, 2010; Abbey et al., 2012). An overall higher net efficiency of nitrogen, phosphorus and potassium was reported in vermicompost through comparative analyses, in comparison to chemical fertilizers or thermophilic composted soil amendments (Sinha et al., 2010). Vermicomposts are rich in bacteria, actinomycetes, fungi, and cellulose-degrading bacteria (Edwards et al., 2010). Vermicomposts are superior quality organic soil amendments because of their excellent biological properties and also linked to nutrient cycling in soil or plant growth media. Variation in palatability, particle size and metabolites of solid organic wastes may influence the performance of earthworm and hence the quality of its end-product (Suthar, 2007). Quality and nutrient status of vermicompost produced varies with the selection of feeding material for earthworms. Therefore, the present study was conducted to evaluate the vermicompost derived from crop residues and cow dung used as feeding materials for earthworms.

\section{Materials and Methods}

The present study was conducted to study the characteristics of fresh vermicompost generated from crop residue biomass and cow dung using epigeic species Eisenia foetida. Vermicompost samples were collected from different vermicompost production units (VCPUs) Bihar Agricultural University Farm, Sabour. Bulk density was measured with graduated cylinder method and particle density of vermicompost was determined by volumetric flask method described by Bashour and Sayegh (2007). Porosity was 
calculated using the equation given by Carter and Gregorich (2008). The moisture content of vermicompost was determined by oven drying the fresh vermicompost up to constant mass as described in Baruah and Barthakur (1997). Maximum water holding capacity was measured using cylinders with a perforated base and as described by Margesin and Schinner (2005). pH and EC were measured by the method described by FCO (1985). Organic carbon was determined by wet digestion method given by Walkley and Black (1935). Total nitrogen present in vermicompost was determined by standard method given by Piper (1966). For total P, K and $\mathrm{S}$ vermicompost samples were digested by diacid digestion. Total phosphorus in the digest was estimated by the vanadomolybdate yellow colour method described by Page et al., (1982). Total potassium was determined by using a known volume of digest (prepared as in total phosphorus) and estimated by flame photometer as described by Page et al., (1982). Total sulphur in the digest was estimated by using $\mathrm{BaCl}_{2}$ crystal as the method given by Tabatabai et al., (1982) with the help of spectrophotometer $(420 \mathrm{~nm})$. Microbial population like the population of bacteria, fungi, actinomycetes, rhizobium, azotobacter, and phosphate solubilising bacteria (PSB) were also taken into account by counting colony forming unit ( $\mathrm{cfu} \mathrm{g}^{-1}$ ) through serial dilution plate technique. Acid and alkaline phosphatase was determined by the colourimetric method given by Tabatabai and Bremner, (1969). Dehydrogenase activity in vermicompost was determined using a spectrophotometer as given by Klein et al., (1971). Microbial biomass carbon was estimated by chloroform fumigation extraction procedure as described by Jenkinson and Powlson (1976) and calculation was made by Vance et al., (1987). The raw materials required for preparation of vermicompost were analysed in the laboratory and these contain as follows:

\begin{tabular}{|l|l|l|l|l|}
\hline $\begin{array}{l}\text { Raw } \\
\text { materials }\end{array}$ & $\mathbf{N}(\mathbf{\%})$ & $\mathbf{P}(\boldsymbol{\%})$ & $\mathbf{K}(\boldsymbol{\%})$ & $\mathbf{S}(\mathbf{\%})$ \\
\hline $\begin{array}{l}\text { Crop } \\
\text { residue } \\
\text { biomass }\end{array}$ & 1.21 & 0.35 & 0.88 & 0.45 \\
\hline $\begin{array}{l}\text { Cow- } \\
\text { dung }\end{array}$ & 0.99 & 0.32 & 0.64 & 0.18 \\
\hline
\end{tabular}

\section{Results and Discussion}

\section{Physical properties of vermicompost}

Physical properties of vermicompost were presented in table 1. Results revealed that bulk density of vermicompost was found to vary from 0.45 to $0.53 \mathrm{~g} \mathrm{~cm}^{-3}$ with an average value of $0.48 \mathrm{~g} \mathrm{~cm}^{-3}$ whereas particle density varied from 1.04 to $1.06 \mathrm{~g} \mathrm{~cm}^{-3}$ with an average value of $1.05 \mathrm{~g} \mathrm{~cm}^{-3}$. These vermicomposts are porous and porosity ranged from 0.49 to 0.58 with a mean value of 0.54 . Studied vermicomposts when collected were having moisture percentage range between 37.3 to 40.2 per cent with an average of 38.87 per cent. The maximum water holding capacity of this vermicompost varied from 364.63 to 401.31 per cent with an average value of 387.24 per cent. Edwards et al., (2010) recommended that the acceptable moisture content of vermicompost ranges from 30 to $50 \%$.

\section{Chemical properties of vermicompost}

Results of laboratory analysis of vermicompost on chemical properties are presented in table 2. $\mathrm{pH}$ of vermicompost was found to range between 6.70 to 7.03 with an average of 6.88. Electrical conductivity varied from 1.80 to $1.82 \mathrm{dS} \mathrm{m}^{-1}$. Organic carbon content varied from 19.32 to $20.16 \%$ with an average value of $19.67 \%$. It was found that among the all primary macronutrients, nitrogen content was highest that ranged between 1.24 to $1.58 \%$ with an average value of $1.41 \%$, followed by potassium content that 
ranged between 0.96 to $1.08 \%$ with an average value of $1.02 \%$ and phosphorus, ranged from 0.39 to $0.45 \%$ with the average value of $0.42 \%$. Secondary macronutrient sulphur content in this vermicompost varied from 0.56 to $0.65 \%$ with an average of $0.61 \%$. It has been found that macronutrient content in the vermicompost was found to slightly higher than used raw bedding materials. Nath et al., (2009) reported that total nitrogen, phosphorus and potassium content were slightly increased in vermicomposts than initial feeding materials. According to Suthar et al., (2005) quality of vermicompost depends on feed quality, microbial biomass and decomposition activities during the process.

Biological and biochemical properties of vermicompost

Under biological properties, population count of bacteria, actinomycetes, fungi, PSB, rhizobium, azotobacter are presented in table 3. Total bacterial and actinomycetes count of fresh vermicompost of crop biomass and cow dung varied from $5.33 \times 10^{7}$ to $6.67 \times 10^{7}$ and $1.67 \times 10^{7}$ to $2.33 \times 10^{7} \mathrm{cfu} \mathrm{g}^{-1}$ dry vermicompost with a mean value of $6.22 \mathrm{x}$ $10^{7}$ and $2.11 \times 10^{7} \mathrm{cfu} \mathrm{g}^{-1}$ dry vermicompost, respectively whereas account of fungi was $14.00 \times 10^{4}$ to $23.67 \times 10^{4} \mathrm{cfu} \mathrm{g}^{-1}$ dry vermicompost with an average value of 17.78 x $10^{4} \mathrm{cfu} \mathrm{g}^{-1}$ dry vermicompost. The population of phosphorus solubilising bacteria (PSB) and azotobacter in the same vermicompost were accounted that ranged from $11.67 \times 10^{6}$ to $15.33 \times 10^{6}$ and $10.33 \times$ $10^{6}$ to $15.33 \times 10^{6}$ with the average values of $13.89 \times 10^{6}$ and $13.11 \times 10^{6} \mathrm{cfu} \mathrm{g}^{-1}$ dry vermicompost, respectively whereas rhizobium bacteria ranged from $3.00 \times 10^{7}$ to $5.67 \times 10^{7}$ with an average value of $4.33 \times$ $10^{7} \mathrm{cfu} \mathrm{g}^{-1}$ dry vermicompost. Therefore, it may be suggested that population count of different microbial properties in the vermicompost of crop residue and cow dung were in the order of total bacteria> rhizobium bacteria> actinomycetes $>$ PSB $>$ azotobacter> fungi.

Table.1 Some important physical properties of vermicompost of crop residue and cowdung

\begin{tabular}{|l|c|c|c|c|}
\hline Properties & VCPU-1 & VCPU-2 & VCPU-3 & Mean \\
\hline B.D. $\left(\mathbf{g ~ c m}^{-3}\right)$ & 0.45 & 0.53 & 0.45 & $0.48 \pm 0.05$ \\
\hline P.D. $\left(\mathbf{g ~ c m}^{-3}\right)$ & 1.04 & 1.03 & 1.06 & $1.05 \pm 0.01$ \\
\hline Porosity & 0.57 & 0.49 & 0.58 & $0.54 \pm 0.05$ \\
\hline Moisture (\%) & 40.20 & 37.30 & 39.10 & $38.87 \pm 1.46$ \\
\hline Max. WHC (\%) & 364.63 & 395.79 & 401.31 & $387.24 \pm 19.78$ \\
\hline
\end{tabular}

Table.2 Some important chemical properties of vermicompost of crop residue and cowdung

\begin{tabular}{|l|c|c|c|c|}
\hline Properties & VCPU-1 & VCPU-2 & VCPU-3 & Mean \\
\hline pH & 6.70 & 6.90 & 7.03 & $6.88 \pm 0.16$ \\
\hline EC $\left(\mathbf{d S ~ m}^{-\mathbf{1}}\right)$ & 1.80 & 1.82 & 1.81 & $1.81 \pm 0.01$ \\
\hline OC $(\%)$ & 20.16 & 19.32 & 19.54 & $19.67 \pm 0.43$ \\
\hline Total N (\%) & 1.40 & 1.58 & 1.24 & $1.40 \pm 0.17$ \\
\hline Total P (\%) & 0.45 & 0.39 & 0.42 & $0.42 \pm 0.03$ \\
\hline Total K (\%) & 1.08 & 1.02 & 0.96 & $1.02 \pm 0.06$ \\
\hline Total S $(\%)$ & 0.63 & 0.65 & 0.56 & $0.61 \pm 0.05$ \\
\hline
\end{tabular}


Table.3 Some important biological and biochemical properties of vermicompost of crop residue and cowdung

\begin{tabular}{|c|c|c|c|c|}
\hline Properties & VCPU-1 & VCPU-2 & VCPU-3 & Mean \\
\hline Bacteria (x 10 cfu g $^{-1}$ dry vermicompost) & 6.67 & 5.33 & 6.67 & $6.22 \pm 0.77$ \\
\hline Actinomycetes ( $\mathbf{x 1 0}^{7} \mathrm{cfu}^{-1}$ dry vermicompost) & 2.33 & 2.33 & 1.67 & $2.11 \pm 0.38$ \\
\hline Fungi (x $10^{4} \mathrm{cfu}^{-1}$ dry vermicompost) & 15.67 & 23.67 & 14.00 & $17.78 \pm 5.17$ \\
\hline PSB (x $10^{6} \mathrm{cfu} \mathrm{g}^{-1}$ dry vermicompost) & 15.33 & 14.67 & 11.67 & $13.89 \pm 1.95$ \\
\hline 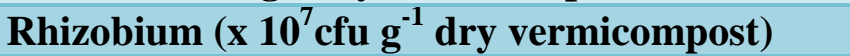 & 5.67 & 3.00 & 4.33 & $4.33 \pm 1.33$ \\
\hline Azotobacter (x $10^{6} \mathrm{cfu}^{-1}$ dry vermicompost) & 15.33 & 10.33 & 13.67 & $13.11 \pm 2.55$ \\
\hline DHA $\left(\mu \mathrm{g}\right.$ TPF $\mathrm{h}^{-1} \mathrm{~g}^{-1}$ of vermicompost $)$ & 57.52 & 92.9 & 98.75 & $83.06 \pm 22.31$ \\
\hline Acid phosphatase ( $\mu \mathrm{g}$ p-nitrophenol $\mathrm{g}^{-1} \mathrm{hr}^{-1}$ ) & 80.22 & 82.46 & 83.84 & $82.17 \pm 1.83$ \\
\hline Alkaline phosphatase ( $\mu \mathrm{g} \mathrm{p}$-nitrophenol $\mathrm{g}^{-1} \mathrm{hr}^{-1}$ ) & 94.02 & 111.43 & 105.57 & $103.67 \pm 8.86$ \\
\hline Microbial Biomass Carbon $\left(\mathrm{mg} \mathrm{kg}^{-1}\right)$ & 479.76 & 502.43 & 512.84 & $498 \pm 16.91$ \\
\hline
\end{tabular}

Dehydrogenase activity of the same vermicompost varied from 57.52 to 98.75 with the mean value of $83.06 \mu \mathrm{g}$ TPF $\mathrm{h}^{-1} \mathrm{~g}^{-1}$ of vermicompost. According to Romaniuk et al., (2011), most of the organic amendments contain partially decomposed carbon material for using soil organisms as an energy source which causes higher rates of respiration. Dehydrogenase activity reflects the whole metabolic activity of microorganisms in a particular area (Dick, 1994). Acid phosphatase activity and alkaline phosphatase activity ranged from 80.22 to 83.84 with an average of 82.17 and 94.02 to 111.43 with mean of $103.67 \mu \mathrm{g}$ p-nitrophenol $\mathrm{g}^{-1} \mathrm{hr}^{-1}$. Microbial biomass carbon content ranged between 479.76 to $512.84 \mathrm{mg} \mathrm{kg}^{-1}$ with an average value of $498.34 \mathrm{mg} \mathrm{kg}^{-1}$. Microbial biomass carbon is evaluated as the most active part of carbon (1-5\% of total carbon). Microbial biomass carbon data reflects the quality of vermicompost as microbes use carbon from easy sources and locked it in their body that normally releases after death (Kumar et al., 2018).

In conclusion, vermicompost contents higher nutrients than the feeding material to the earthworm. It is a natural source of organic fertilizer that contains huge numbers of various kinds of plant beneficial microorganisms and enzymes and other important biochemical substances. Therefore, it may be considered as a natural biofertilizer.

\section{References}

Abbey, L., Rao, S. A., Hodgins, L. N., and Briet, F. 2013. Drying and Rehydration of Vermicasts Do Not Affect Nutrient Bioavailability and Seedling Growth. American Journal of Plant Nutrition and Fertilization Technology. 3(1): 12-21.

Abbey, L., Young, C., Teitel-Payne, R. and Howe, K. 2012. Evaluation of Proportions of Vermicompost and Coir in a Medium for Container-grown Swiss chard. Int. J. Veg. Sci. 18: 109-120.

Baruah, T. C and Barthakur, H. P. 1997. A Textbook of Soil Analysis. Vikas Publishing House Pvt. Ltd. Pp. 1-334.

Bashour, I. and Sayegh, H. A. 2007. Methods of Analysis for Soils of Arid and Semiarid Regions. Food and Agriculture Organization of the United Nations, Rome. Pp. 34-39.

Bhuvaneshwari, S., Hiroshan, Hettiarachchi and Jay, N, Meegoda. 2019. Crop Residue Burning in India: Policy Challenges and Potential Solutions. Int. J. Environ. Res. Public Health. 16:832- 
851. (doi:10.3390/ijerph16050832).

Carter, M. R. and Gregorich, E. G. 2008. Soil Sampling and Methods of Analysis. 2nd ed. Canadian Society of Soil Science. Taylor \& Francis Group, LLC. Pp. 743 760.

Dick, R. P. 1994. Soil Enzyme Activity as an Indicator of Soil Quality. In: Doran JW et al., editors. Defining Soil Quality for a Sustainable Environment. Madison, WI. Pp. 107-124.

Dominguez, J. 2004. State of the Art and New Perspectives in Vermicomposting Research. (Eds. Edwards, C.A.). Earthworm Ecology, CRC Press, Boca Raton, Pp. 401-425.

Edwards C., Arancon N. Q., Sherman R. L. 2010. Vermiculture Technology. Earthworms, Organic Wastes, and Environmental Management. CRC Press, Pp. 623. (ISBN 9781439809877).

Fertilizer Control Order. 1985. Biofertilizers and organic fertilizers in Fertilizer (control) order, 1985. Published by National Centre of Organic Farming, Dept. of Agriculture and Corporation, Ministry of Agriculture, GoI.

Jenkinson, D. S. and Powlson, D. S. 1976. The effects of biocidal treatments on metabolism in soil-I. Fumigation with chloroform. Soil Biol. Biochem. 8: 167177.

Klein, D. A., Loh, T. C. and Goulding, R. L., 1971. A rapid procedure to evaluate dehydrogenase activity in soil of low organic matter. Soil Biology and Biochemistry 3: 385-387.

Kumar, Ajeet., Paul, Sankar Ch., Kumar, Amarjeet. and Rani, Mukta. 2018. Comparative Assessment of Physicochemical and Biological Quality Characters of Vermicompost from Different Biomass Substrates. Int. J. Curr. Microbiol. App. Sci. 7(1): 89-97.

Margesin, Rosa and Schinner, Franz. 2005. Manual for Soil Analysis - Monitoring and Assessing Soil Bioremediation. Soil Biology. Springer-Verlag Berlin Heidelberg Publication. 5: 1-366.

Nada, W. M., van Rensburg, L., Claassens S. and Blumenstein, O. 2011. Effect of Vermicompost on Soil and Plant Properties of Coal Spoil in the Lusatian Region (Eastern Germany). Commun. Soil. Sci. Plant. Anal. 42: 1945-1957.

Nath, G., Singh, K. and Singh, D. K. 2009. Chemical Analysis of Vermicomposts / Vermiwash of Different Combinations of Animal, Agro and Kitchen Wastes. Australian Journal of Basic and Applied Sciences. 3(4): 3671-3676.

National Policy for Management of Crop Residues (NPMCR). 2014. Department of Agriculture and Cooperation (Natural Resource Management Division), Ministry of Agriculture, GoI. Available online:

http://agricoop.nic.in/sites/default/files/ NPMCR_1.pdf (accessed on 16 Sept. 2020).

Page, A. L., Miller, R. H. and Keeney, D. R. (eds). 1982. Methods of Soil Analysis: Part 2, Chemical and Microbiological Properties. Agronomy Series No 9, American Society of Agronomy, Madison, WI.

Pattnaik, S. and Reddy, M. V. 2010. Nutrient Status of Vermicompost of Urban Green Waste Processed by three Earthworm Species- Eisenia fetida, Eudrilus eugeniae and Perionyx excavates. Applied and Environmental Soil Science. 2010: 1-13.

Piper, C. S. 1966. Chemical Analysis Saline Soil. Soil and Plants Analysis. Hans Publication, Bombay, India.

Pramanik, P., Ghosh, G.K., Chosal, P. K., Banik, P. 2007. Changes in organic - C, $\mathrm{N}, \mathrm{P}$ and $\mathrm{K}$ and enzyme activities in vermicompost of biodegradable organic wastes under liming and microbial inoculants. Biores. Technol. 98:2485- 
2494.

Romaniuk, R., Giuffré, L. and Romero, R. 2011. A Soil Quality Index to Evaluate the Vermicompost Amendments Effects on Soil Properties. Journal of Environmental Protection. 2: 502-510.

Sinha, R. K., Agarwal, S., Chauhan, K. and Valani, D. 2010. The Wonders of Earthworms and its Vermicompost in Farm Production: Charles Darwin's Friends of Farmers, with Potential to Replace Destructive Chemical Fertilizers. Agric. Sci. 1: 76-94.

Suthar, S. 2005. Potential Utilization of Guar Gum Industrial Waste in Vermicompost Production. Bioresource Technology. 97: 2474-2477.

Suthar, S., 2007. Composting potential of Perionyx sansibaricus (Perrier) in different waste material. Bioresource Technology. 98: 1231-1237.

Tabatabai, M. A. 1982. Sulphur. In: Page A.L., Freney J.R., Miller R.H. (eds.): Methods of Soil Analysis. Part II.
Chemical and Microbiological Properties. ASA-CSSA-SSSA, Madison. Pp. 501-538.

Tabatabai, M. A. and Bremner, J. M. 1969. Use of p-nitrophenyl Phosphate for Assay of Soil Phosphatase Activity. Soil Biol. Biochem. 1: 301-307.

Glossary of Environment Statistics, United Nations, 1997, Studies in Methods; Series F, 67; Department for Economic and Social Information and Policy Analysis, Statistics Division: New York, NY, USA,; Volume 96.

Vance, E. D., Brookes, P. C. and Jenkinson, D. S. 1987. An Extraction Method for Measuring Soil Microbial Biomass C. Soil Biol. Biochem. 19: 703-707.

Walkley, A. and Black, I. A. 1935. An Examination of Digestion Method for Determining Soil Organic Matter and a Proposed Modification of the Chromic Acid Titration Method. Soil Sci. 37: 2937.

\section{How to cite this article:}

Varsha Kumari, Sankar Ch. Paul, Mahendra Singh, Ajeet Kumar and Amit Kumar Pradhan. 2020. Quality Characterisation of Vermicompost Produced from Crop Residue and Cow Dung. Int.J.Curr.Microbiol.App.Sci. 9(10): 776-782. doi: https://doi.org/10.20546/ijcmas.2020.910.093 